\title{
Compartment syndrome presenting as ischemia following extravasation of contrast material
}

\author{
Aaron Grand $\mathrm{MD}^{1}$, Brian Yeager ${ }^{2}$, Ronit Wollstein $\mathrm{MD}^{2}$
}

\begin{abstract}
A Grand, B Yeager, R Wollstein. Compartment syndrome presenting as ischemia following extravasation of contrast material. Can J Plast Surg 2008;16(3):173-174.

A case of acute compartment syndrome of the forearm, resulting from contrast dye extravasation that presented as upper extremity ischemia, is described. Timely surgical intervention resulted in an excellent outcome. When extravasation of dye occurs, the patient should be evaluated for compartment syndrome despite the possible lack of typical symptoms.
\end{abstract}

Key Words: Compartment syndrome; Contrast dye; Extravasation

\section{Syndrome du compartiment prenant la forme d'une ischémie après l'extravasation d'un pro- duit de contraste}

On décrit ici un cas de syndrome du compartiment aigu consécutif à l'extravasation d'un produit de contraste au niveau de l'avant-bras et ayant pris la forme d'une ischémie du membre supérieur. Une intervention chirurgicale prompte a donné d'excellents résultats. Lors de l'extravasation d'un produit de contraste, il faut examiner le patient pour vérifier la présence d'un syndrome du compartiment, et ce, malgré l'absence possible de symptômes typiques.
Compartment syndrome of the forearm following injection Uof contrast material is a relatively rare complication but has been described (1-5). Although soft tissue infiltration of intravenous contrast occurs with an estimated frequency of $0.7 \%$, compartment syndrome rarely follows (5). Surgical intervention after extravasation of contrast material is rarely needed, and severe complications are unusual. However, when compartment syndrome does occur, emergent fasciotomy is clearly required to prevent the devastating consequences of delayed treatment.

We present a case of compartment syndrome of the forearm, resulting directly from contrast dye injection. The patient developed immediate onset of severe pain and rapidly developed upper extremity ischemia. To the best of our knowledge, compartment syndrome rarely presents initially as hand ischemia (6).

We believe that all cases of upper extremity contrast extravasation should be evaluated promptly by an upper extremity specialist - despite the possible absence of typical symptoms - to rule out the possibility of compartment syndrome.

\section{CASE PRESENTATION}

A 48-year-old woman presented to the emergency department with the complaint of pain due to a chronic dental abscess. Because of the concern of a fistula extending into the maxillary sinus, a computed tomography scan of the face was performed with the use of intravenous contrast. A total of $53 \mathrm{~mL}$ of Omnipaque 350 contrast dye (Amersham Health Inc, USA) was injected using a power injector. The patient immediately complained of forearm pain and the contrast was noted to have infiltrated the tissues of the forearm. Hand surgery consultation was requested.
The patient was evaluated within $1 \mathrm{~h}$ of the consultation request. At that time, the patient's hand was extremely pale and cool. The patient was able to achieve only minimal active range of motion of the fingers or wrist. Passive range of motion induced excruciating pain. Distal sensation was grossly diminished. The subcutaneous tissues of the forearm were only slightly swollen, but the flexor and extensor compartments were very firm. Radial and ulnar pulses were not palpable. Capillary refill could not be detected.

A diagnosis of forearm compartment syndrome was made and the patient was taken immediately to the operating room. Under general anesthesia, a carpal tunnel release and volar and dorsal forearm fasciotomies were performed, with release of all muscle compartments. The muscle tissue bulged into the wounds. A moderate amount of clear, slightly viscous fluid was irrigated from the subcutaneous and subfascial tissues. Distal pulses were immediately restored. All tissues appeared viable, and no debridement was required. Hemostasis was accomplished with a combination of direct pressure and electrocautery. The dorsal wound was able to be closed primarily. The volar skin edges were loosely reapproximated where possible, and the extremity was bandaged and elevated.

Seven days later, the patient was returned to the operating room for a delayed primary closure of the volar wound. The patient was discharged from the hospital several days later. Four weeks from the initial injury, the patient had regained almost full active and passive range of motion of all joints of the extremity, and two-point discrimination was $5 \mathrm{~mm}$ or less in the tips of all digits of the hand. Full active motion was restored with continued hand therapy.

\footnotetext{
${ }^{1}$ Department of Orthopedic Surgery; ${ }^{2}$ Department of Surgery, Division of Plastic and Reconstructive Surgery, University of Pittsburgh Medical Center, Pittsburgh, Pennsylvania, USA

Correspondence: Dr Ronit Wollstein, 3550 Terrace Street. Pittsburgh, Pennsylvania 15261, USA. Telephone 412-648-2381, fax 412-648-1987, e-mailwollsteinr@upmc.edu
} 


\section{DISCUSSION}

Iatrogenic compartment syndrome is likely more common than suggested in published accounts and may result from causes other than contrast dye extravasation $(7-10)$.

Classic signs and symptoms of compartment syndrome are well-known, and include pain, pallor, paresthesias and pulselessness. However, it is commonly believed that these are late signs and are often not present until irreversible tissue damage has occurred. Physical examination with palpation of the compartments in question is thought to be one of the most reliable methods of diagnosis of compartment syndrome. When the diagnosis remains unclear, compartment pressures can be measured directly using either a specially made device such as the Stryker Intra-Compartmental Pressure Monitor System (Stryker Instruments, USA), or a manometer as described by Wilson et al (11).

We present a case of compartment syndrome caused by intravenous injection of contrast dye in the trauma setting. This case is exceptional because the patient presented with immediate symptoms of upper extremity ischemia. This acute ischemic presentation improved rapidly upon fasciotomy. In the differential diagnoses for the hand ischemia in this scenario were arterial or venous thrombosis, as well as emboli and other vascular diagnoses.

The patient was able to describe her symptoms, and had obvious signs of increased compartment pressure. Following surgery, she recovered very quickly with no sequelae except the presence of scars.

The present case illustrates the need for a high level of suspicion when such an injury occurs despite the possible lack of typical symptoms, and the excellent results that can be achieved with prompt intervention. If the diagnosis is not clear, compartment pressures should be measured; pressures above $35 \mathrm{mmHg}$ are generally considered to be an indication for immediate fasciotomy. If doubt remains, fasciotomy should be strongly considered, so as to avoid the devastating consequences of untreated compartment syndrome.

\section{REFERENCES}

1. Bellin MF, Jakobsen JA, Tomassin I, et al. Contrast medium extravasation injury: Guidelines for prevention and management. Eur Radiol 2002;12:2807-12.

2. Benson LS, Sathy MJ, Port RB. Forearm compartment syndrome due to automated injection of computed tomography contrast material. J Orthop Trauma 1996;10:433-6.

3. Selek H, Ozer H, Aygencel G, Turanli S. Compartment syndrome in the hand due to extravasation of contrast material. Arch Orthop Trauma Surg 2007;127:425-7.

4. Stein DA, Lee S, Raskin KB. Compartment syndrome of the hand caused by computed tomography contrast infiltration. Orthopedics 2003;26:333-4.

5. Wang CL, Cohan RH, Ellis JH, Adusumilli S, Dunnick NR. Frequency, management, and outcome of extravasation of nonionic iodinated contrast medium in 69,657 intravenous injections. Radiology 2007;243:80-7.

6. Christiansen SD, Desai NS, Pulito AR, Slack MR. Ischemic extremities due to compartment syndromes in a septic neonate. J Pediatr Surg 1983;18:641-3.

7. Buck ML, Wiggins BS, Sesler JM. Intraosseous drug administration in children and adults during cardiopulmonary resuscitation. Ann Pharmacother 2007;41:1679-86.

8. Edwards JJ, Samuels D, Fu ES. Forearm compartment syndrome from intravenous mannitol extravasation during general anesthesia. Anesth Analg 2003;96:245-6.

9. Erickson BA, Yap RL, Pazona JF, Hartigan BJ, Smith ND. Mannitol extravasation during partial nephrectomy leading to forearm compartment syndrome. Int Braz J Urol 2007;33:68-71.

10. Simmons CM, Johnson NE, Perkin RM, van Stralen D. Intraosseous extravasation complication reports. Ann Emerg Med 1994;23:363-6.

11. Wilson SC, Vrahas MS, Berson L, Paul EM. A simple method to measure compartment pressures using an intravenous catheter. Orthopedics 1997;20:403-6. 